\title{
Conceptual Metonymy and the Physiological, Poetic Expression of Emotion
}

Studies on a Keatsian Corpus

La métonymie conceptuelle et l'expression physiologique et poétique de l'émotion :étude d'un corpus keatsien

\section{Katrina Brannon}

\section{(2) OpenEdition}

\section{Journals}

Electronic version

URL: http://journals.openedition.org/tipa/2881

DOI: 10.4000/tipa.2881

ISSN: 2264-7082

\section{Publisher}

Laboratoire Parole et Langage

\section{Electronic reference}

Katrina Brannon, «Conceptual Metonymy and the Physiological, Poetic Expression of Emotion », TIPA. Travaux interdisciplinaires sur la parole et le langage [Online], 35 | 2019, Online since 03 July 2019 connection on 25 July 2019. URL : http://journals.openedition.org/tipa/2881 ; DOI : 10.4000/tipa.2881

This text was automatically generated on 25 July 2019.

\section{(i)

La revue TIPA. Travaux interdisciplinaires sur la parole et le langage est mise à disposition selon les termes de la licence Creative Commons Attribution - Pas d'Utilisation Commerciale - Pas de Modification 4.0 International. 


\title{
Conceptual Metonymy and the Physiological, Poetic Expression of Emotion
}

\author{
Studies on a Keatsian Corpus
}

La métonymie conceptuelle et l'expression physiologique et poétique de l'émotion :étude d'un corpus keatsien

Katrina Brannon

\section{0 . Role(s) of Conceptual Metonymy in the Expression of Emotion}

1 This article will focus on linguistic expression of emotion and emotional experience, expressed by way of conceptual metonymy. Our concentration here will thus be centered on the physical and/or physiological-and thus, somewhat more concrete-aspect of emotion. The accepted theories on conceptual metonymy, embodied emotion, as well as the research performed on the Keatsian corpus-a selection of thirty-five poems by John Keats, from all periods of his career and of all types-upon which this research is based, have led to the decision that the analysis of conceptual metonymy as a means for the expression of emotion is the richest and most evocative manner of analyzing the physiological domain of emotion. The "physiological domain" of emotion, for our purposes, can be defined as the internal and external physical outpourings of emotional experience. Emotional experience, once again, for our purposes, includes its linguistic verbalizations-the way in which we express emotion via language-due to the fact that "that conceptual metonymies of emotions reflect, at least for the most part, real universal physiology," (Kövecses, 2000: 177).

2 Our endeavor here is to examine how the body/mind is present in the Keatsian conceptualization and realization of emotion. G. Bachelard reminds us of the importance of this type of expression within the poetic text, in suggesting: "le poète anime une 
dialectique plus subtile. Il révèle à la fois, dans le même instant, la solidarité de la forme et de la personne. Il prouve que la forme est une personne et que la personne est une forme, ${ }^{1 "}$ (Bachelard, 1943: 232).

\section{Theoretical Background; Introduction}

3 Before diving into the specific analyses of occurrences of conceptual metonymy within our Keatsian corpus, let us first clarify the notion of conceptual metonymy. Metonymy can be defined as "[...] a cognitive process in which one conceptual entity, the vehicle, provides access to another conceptual entity, the target, within the same idealized cognitive model, 2" (Radden \& Kövecses, 2009: 21). Two examples are statements such as "She was my ruin," (STATE/EVENT FOR THING/PERSON/STATE CAUSING IT) or "She is my joy," ( EMOTION FOR CAUSE OF EMOTION) (Radden \& Kövecses, 2009: 14).

4 The metonymies to be analyzed here will, as a general pattern, take the physiological/ physical expression of an emotional experience (i.e.: tears, blushing, temperature changes, variations in heart rate...) as the vehicle which opens both the linguistic and cognitive doors to the emotional experience itself, which here may be considered as the target domain.

\subsection{The Role of Consciousness}

5 A. Damasio, in his (more or less) Spinozian ${ }^{3}$ approach to emotion and emotion concepts, emphasizes the role of consciousness within the realm of emotional experience. He defines consciousness in the following manner:

The organism in question is that within which consciousness occurs; the object in question is any object that gets to be known in the consciousness process, and the relationships between organism and object are the contents of the knowledge we call consciousness. Seen in this perspective, consciousness consists of constructing knowledge about two facts: that the organism is involved in relating to some object, and that the object in the relation causes a change in the organism. (Damasio, 1999: 20).

Based on Damasio's definition-which we adhere to-"consciousness and emotion are not separable," (Damasio, 1999: 16).

Damasio's definition of consciousness rings particularly true when attempting to fully grasp the role of the body in emotional experience. The body's role can be understood as the ways in which the body affects or is affected by (bringing us, once again, back to Spinoza and the affects [LeBuffe, 2015]) the "mental" experience of emotion-as we are typically aware, at least to a certain extent, of the changes and reactions taking place within our bodies during an emotional experience ${ }^{4}$. In light of this, we are particularly interested in here is the "moment of emergence" of the emotion (Damasio, 2003: 86): the moment when the physical system attains its "critical pitch [...] [and] the process is felt," (Damasio, 2003: 86). This "feeling" of the process, of the experience of emotion, is what we mean by "consciousness" here.

8 Consciousness can be understood as "stepping into the light": "[...] the specific moment when, as we sit waiting in the audience, the door to the stage opens and a performer steps into the light; or, to take the other perspective, the moment when a performer who waits in semidarkness sees the same door open, revealing the lights, the stage, and the 
audience," (Damasio, 1999: 3). The importance of consciousness within emotional experience is emphasized by J.P. Sartre, who refers to emotional experience as a "state of consciousness, ", or, as a moment in which the experiencer of the emotion finds herself in the possession of a "moved consciousness" (Sartre, 1939: 16).

Moreover, the role of language as a means of expression of emotion buttresses the centrality of consciousness within emotional experience. To begin with, the verbalization of an emotional state-including its various causes, effects, and consequences-stems from a certain level of awareness concerning the emotional state itself. Expressing this in a poetic manner requires, perhaps, an even more elevated level of consciousness (Tsur, 2008: 412). The consciousness required to depict the physiological effects and results of emotional experience is thus a form of consciousness based on a level of consciousness relative to oneself, but also to the surrounding world: as is the devoir of the artist and her/his creation. We can thus apprehend that the poetic act as enumerated (above) by G. Bachelard corresponds with not only R. Tsur's comprehension of the role of consciousness (of poet as well as within the poetic text itself) but also, to A. Damasio's straightforward definition of consciousness, as "[...] the unified mental pattern that brings together the object and the self," (Damasio, 1999: 11) ${ }^{7}$.

\subsection{Keatsian Bodily Expression of Emotion; Emotive and Expressive Choices}

10 Emotion-encompassing the physical and the mental-and consciousness are thus inherently connected, or rather, inseparable. The links and parallelisms between these two entities ultimately reinforce the role of the body within emotion, as "[...] just like emotion, consciousness is aimed at the organism's survival, and that, just like emotion, consciousness is rooted in the representation of the body," (Damasio, 1999: 37). The body is therefore essential to a full, profound comprehension and assertion of emotion: hence the choice to concentrate this text on this complex, ever-present, part of ourselves. The interest here, however, goes beyond mere concentration or curiosity concerning the body. The poetic representation of the body within the emotional (and thus, conscious) context is our real objective here, and this, based on the belief that "poetry is a constant struggle to overcome the tyranny of conceptual language, and convey vague, diffuse qualities with the help of words," (Tsur, 2008: 251).

11 Keatsian poetry is rich in emotional content. This is accomplished by way of the exploitation of a wide and profound range of linguistic and conceptual tools. This paper has as its focus one specific tool: the metonymic verbalization of the physiological side of emotional experience, or "conceptualized physiology," (Kövecses, 2000: 162). Our approach will be organized around the instances of conceptual metonymies, relative to the bodily expression of emotion, found within our Keatsian corpus. We will begin with a brief analysis of the more global conceptual metonymies that are present, to a certain extent, in all of the extracts of the poems examined here. Then, we will continue on to the analyses of the other conceptual metonymies verbalized throughout our corpus which have more punctual or specific utilizations, which will be organized from those having the most occurrences within the corpus to those having the least. The analyses will focus on the language used to verbalize the metonymies, in the semantic as well as the grammatical sense (if we wish to separate the two), as well as the context, the plot of the 
poem (if applicable), the poetic effects, and the global effect of the expression of emotion that all of the above play into.

\subsection{Central / Universal Conceptual Metonymies}

12 As is the case with conceptual metaphors ${ }^{8}$, the existence of a delineative, chain-like structure within the development of the linguistic expression of conceptual metonymy is observable in the realms of both language and thought. That is, both metaphors and metonymies may be apprehended as beginning with broader expressions and/or verbalizations, which then taper off to more precise verbalizations ${ }^{9}$.

Some of these broader conceptual metonymies have proven to be exceedingly present in our Keatsian corpus. The global, universal quality of these metonymies could be easily compared with those of the "master metaphor for emotion" of EMOTION IS FORCE (Kövecses, 2000: 63-64). These metonymies act as a conceptual basis for the apprehension and expression of the role of the physical body within emotional experience. The two conceptual metonymies that possess this role are PHYSIOLOGICAL AND EXPRESSIVE RESPONSES OF AN EMOTION FOR AN EMOTION and EFFECTS OF A STATE FOR THE STATE (Kövecses, 2000: 134). All of the instances of conceptual metonymy to be examined throughout the forthcoming pages represent either one or both of the above metonymies (thus, they will not be mentioned in each poetic analysis). We view them thus as points of departure, upon and within which the other, more precise conceptual metonymies find their conceptual, structural, and linguistic foundations. Let us note that this gives rise to a complementary, or combinatory, utilization of conceptual metonymy, which can easily be linked back to G. Lakoff and M. Turner's conception of the poetic exploitation of figurative language (Lakoff \& Turner, 1989: 66-71), thus reinforcing the poeticity of the expressions themselves, as well as the texts as a whole.

\section{Corpus-Based Metonymical Analyses}

The theoretical groundwork of our analyses having been laid out, let us now dive into the specific corpus-based analyses of emotional metonymy. The extracts to be examined come from the following works: "Ode to a Nightingale," "Ode to Psyche," "Ode on a Grecian Urn," "Ode on Melancholy," "To Hope," "Ode on Indolence," "Isabella, or the Pot of Basil," "O blush not so!" and "La Belle Dame Sans Merci."

\subsection{Change in Color of Face for Emotion (Blushing for Love)}

The first conceptual metonymy to be examined is CHANGE IN COLOR OF FACE FOR EMOTION (BLUSHING FOR LOVE) (Kövecses, 2000: 134), of which our corpus offers five instances, referring to varying facets of the possibilities of the change in the color of the facial skin as a response, reaction, or component of certain emotional experiences. We find examples of both the loss and the gain of color in the face: the latter is often depicted as blushing. This expression is metonymical as the bodily reaction of the change in face color is perceived as the expression of the emotion itself: the color of the skin is directly associated with the emotion in question. Let us consider the examples in a grouped fashion, based on their color-based nuances: 
(1) Where youth grows pale, and spectre-thin, and dies; / Where Beauty cannot keep her lustrous eyes [...]

"Ode to a Nightingale," lines 25-26.

(2) A whole long month of May in this sad plight / Made their cheeks paler by the break of June: [...]

"Isabella, or the Pot of Basil," lines 25-26.

(3) I see a lily on thy brow, / With anguish moist and fever-dew, / And on thy cheeks a fading rose / Fast withereth too.

"La Belle Dame Sans Merci," lines 9-12.

(4) There's a blush for won't, and a blush for shan't, / And a blush for having done it; [...]

"O blush not so!" lines 5-6.

(5) O blush not so! O blush not so! / Or I shall think you knowing; / And if you smile, the blushing while, / Then maidenheads are going.

"O blush not so!" lines 1-4.

The above examples are organized from palest to rosiest, in regard to the description of the subject undergoing the emotional experience exteriorized by way of the bodily expression of change in facial color. (1) and (2) depict poetic subjects (specifically, youths, rendering their paleness all the more notable) in the state of "becoming" pale, or in the process of "losing" color, verbalized by way of a lexical verb tied together with an adjective: "grows pale" and "made [their cheeks] paler." The loss of color, or, in more adept physiological terms, the diminution in blood flow to the face, is gradual in both cases. This is reflected by way of the verbal structure itself and the semantics of the lexical verbs chosen to express the given states, as well as the perfective aspect in which the verbs appear here, providing a maximal, heterogeneous viewing frame: the process of diminution of blood flow is thus heavily emphasized. The paleness in these cases is metonymic for the experience of a negative emotional state: one that ebbs away at the zest for life and results in a physical toll being taken on the experiencer. In (1), the emotion represented metonymically is the darkness and despondency of a world lacking in artistic creation and freedom. In (2), it is lovesickness, or the possibility of unrequited love, that results in a difficult emotional state for Isabella and Lorenzo.

(3) may be apprehended as an intermediary case: that is, in between the state of paleness and the state of blushing. The "palely loitering" knight-at-arms [v. 1-2] is depicted as having once been the possessor of rosy cheeks-thus reflecting a more positive emotional experience, in this case, lust and sexual fulfillment-but this rosiness is now withering, and has become comparable with the coloration of a lily (thus, white) on other parts of the face. As in (1) and (2), these lines verbalize a transformative process.

In (4) and (5), the reader encounters two occurrences of heavy blushing: (4) being slightly more intensified than (5), which is emphasized by the exhortations (seemingly against, but we know better...) the blushing of the young maid in the first two lines of the extract. The increase in blood flow to the face, verbalized in these lines is indicative of a positiveor at least, arousing-experience, both emotional and physical, on the part of the interlocutor. Furthermore, the blushing seems to result in a positive, excitable (albeit 
somewhat tortured) state on the part of the speaker, thus creating a doubling-up of the emotional intensity taking place here.

We may also note the differences in terms of the pure mention, or cause of the emotion, found between these verses. (1) and (3) do not mention the emotion itself whatsoever, nor the cause of the emotional state expressed, rendering them highly metonymic. (2), (4), and (5) allude to various reasons for the physical state expressed: ("this sad plight"; "there's a blush for shan't..."). However, they do not explicitly mention the emotion itself, nor its cause, providing a highly figurative quality to these expressions, and to a certain extent-particularly in (4) and (5)-engaging in lighthearted games with the reader.

\subsection{Change in Heart Rate for Emotion}

The following emotionally-centered metonymy to be examined is CHANGE IN HEART RATE FOR EMOTION (Kövecses, 2000: 134). The verbalization of this conceptual metonymy allows for the crystallization of the ways in which the pulse varies as an element of emotional experience, typically slowing down in the instances of a negative emotion (i.e. dealing with sadness, depression, or lack of stimulation leading to various emotional responses) and speeding up in the cases of more positive emotions (being, love, happiness, or increased stimulation, once again leading to varied reactions of the affective type). Our corpus has provided us with five occurrences of this type of metonymy, from five different Keatsian works. They have been ordered in terms of slowness to rapidity of the heartbeat.

(6) My heart aches, and a drowsy numbness pains / My sense, as though of hemlock I had drunk, / Or emptied some dull opiate to the drains / One minute past, and Lethe-wards had sunk...

"Ode to a Nightingale," lines 1-4.

(7) The blissful cloud of summer-indolence / Benumb'd my eyes; my pulse grew less and less; / Pain had no sting, and pleasure's wreath no flower: / O why did ye not melt, and leave my sense / Unhaunted quite of all but-nothingness?

"Ode on Indolence," lines 16-20.

(8) Should e'er unhappy love my bosom pain, / [...] o let me think it is not quite in vain / To sigh out sonnets to the midnight air!

"To Hope," lines 12-14.

(9) And for that poor Ambition! It springs / From a man's little heart's short fever-fit [...]

“Ode on Indolence," lines 34-35.

(10) So said he one fair morning, and all day / His heart beat awfully against his side; / And to his heart he inwardly did pray / For power to speak; but still the ruddy tide / Stifled his voice, and pulsed resolve away"Isabella, or the Pot of Basil," lines 40-45.

(6) and (7) present clear-cut instances of the slowing of the heart rate of the speaker, albeit perceived and received differently by the latter. In (6), the emotional situation is tied to overall sensations of pain ("my heart aches")-which gradually lessen throughout 
the verses at hand-and the slowing of the pulse, alluded to by references of the effects of opiates and tendencies toward intensive states of rest. (6) is further reinforced in "Ode to a Nightingale" by verbalizations of the slowing of the brain: "though the dull brain perplexes and retards..." (v. 34). The body/mind here is illustrated as being on the verge of shutdown. In (7), the slowing of the heart rate is intertwined with the profound state of indolence in which the speaker finds himself, which is characterized by a state of overall lack of sensation, emphasized by the "benumb'd eyes" and the fact that "pain had no sting, and pleasure's wreath no flower." This state of unfeeling slothfulness is visibly the state desired by the speaker, as the exhortative statement at the end of the abstract emphasizes.

(8) and (9) are intermediary states-placed between the two ends of the scale of speeding up and slowing down-given that the emotions expressed within these verses are revelatory of a certain ambiguity. (8) is an act of verbalization of the potential of emotional pain (due to heartbreak, "unhappy love,"), rendered metonymical by the reference to physical pain in the chest, thus ultimately reflective of a variation in heart rate, either slowing down or speeding up. However, in contrast to the notion of the potential pain expressed here, the poem is one of an overall hopeful tone (as its title suggests). The pain, if it does take place, is placed in contrast with a second potential, future action, emphasized here by the use of the imperative use of the verb let, part of the "Greater Modal System" (Talmy, 1988: 81; Brannon 2018: 250-258) thus directing us by way of two grammatical and semantic senses towards the future, which is artistic creation. In other words, the development of the positive out of the negative. The use of the metonymy CHANGE IN HEART RATE FOR EMOTION here allows for this contrast to be emphasized and verbalized to its fullest. (9) is a highly similar instance, with a fairly positive emotional and mental reaction, "ambition," springing from the intensification of the heart rate of man. We may, however, remark upon the fact that this poem is indeed an "Ode on Indolence," thus, a contradictory state in regard to an ambitious one. Once again, as in (8), the physically-based emotional metonymy allows for the full elaboration of such a contrast. The emotive state of ambitiousness is even, to a certain extent, degraded within the verses themselves, by way of adjectival elements expressing diminutive stature: little, short, and fit.

(10) is an explicit verbalization of the delineation of this metonymy in the sense of INCREASE IN HEART RATE FOR EMOTION. The emotion referred to here is love (tied with the nervousness that so often accompanies new love): "his heart beat awfully against his side." Lorenzo is overtaken by his love for Isabella, a situation which is expressed by way of the rapid increase of his pulse, allowing for intense, figurative expression of his emotional state.

\subsection{Physical Agitation for Emotion}

The emotional, physiological conceptual metonymy PHYSICAL AGITATION FOR EMOTION ( Kövecses, 2000: 82) is highly present within our Keatsian corpus: we have found eight instances of this metonymy. It's global quality allows for a wide range of emotions and their various physical agitations or responses to be viewed through its prism. The extracts are organized in terms of the intensity of the physical agitations verbalized within them, from the most delicate to the most intense: 
(11) They could not in the self-same mansion dwell / Without some stir of heart, some malady; / They could not sit at meals but feel how well / It soothed each to be the other by; / They could not, sure, beneath the same roof sleep / But to each other dream, and nightly weep.

"Isabella, or the Pot of Basil," lines 3-8.

(12) And with sick longing all the night outwear, / To hear her morning-step upon the stair.

"Isabella, or the Pot of Basil," lines 24-25.

(13) The weariness, the fever, and the fret / Here, where men sit and hear each other groan; / Where palsy shakes a few, sad, last gray hairs [...]

"Ode to a Nightingale," lines 23-25.

(14) Yes, I will be thy priest, and build a fane / In some untrodden region of my mind, / Where branched thoughts, new grown with pleasant pain, / Instead of pines shall murmur in the wind: [...]

"Ode to Psyche," lines 50-54.

(15) Should e'er unhappy love my bosom pain, / [...] o let me think it is not quite in vain / To sigh out sonnets to the midnight air! / Sweet Hope, ethereal balm upon me shed, $[. .$.

"To Hope," lines 24-27.

(16) Or if thy mistress some rich anger shows, / Emprison her soft hand, and let her rave, / And feed deep, deep upon her peerless eyes.

"Ode on Melancholy," lines 18-20.

For the ease of our analyses here, we may group these six extracts into two separate, more precise clusters in terms of the similarity of the emotion expressed by way of the conceptual metonymy PHYSICAL AGITATION FOR EMOTION as well as the physical tumult central to the verbalization of the metonymy itself. (11), (12), and (13) may be categorized together due to the fact that they express outward, physical manifestations of illness. (11) and (12) are quite simple to analyze together as the poetic context is the same, and thus, the emotions expressed by way of this metonymy (and in other ways) are also the same. What is at play here is the agitation, both in the body and the mind, created by the experience of fresh, young (potentially unrequited) love, coupled with lust. The "sickness" expressed here, by way of nominal elements-thus nominating these physical agitations as secondary subjects, providing them with their own lives-such as "stir of heart," "malady," and "sick longing," may thus literally be considered as an instance of "lovesickness," resulting in motion, movement, and dynamism. Moreover, temporary relief is within the reach of the young lovers ("it soothed each to be the other by"; "to hear her morning-step upon the stair"). (13) places the reader in a different type of context: we are faced with the "weariness, fever, and fret," coupled with groaning and shaking. These physical agitations are related to the elderly-near-death-temporality in which the speaker as well as his co-actors find themselves. The agitated qualities of illness are present here; but they are combined with a certain vacuity, lacking the fervent quality inherent in the examples from "Isabella." 

and (15) are similar in the sense that the pain referred to within them is construed positively, as it is either referred to as the cause or the effect of emotional, intellectual, or creative growth or productivity: "branched thoughts, new grown with pleasant pain"; "O let me think it is not quite in vain / To sigh out sonnets to the midnight air!" Moreover, these extracts both possess an exhortative element, increasing their poetic and emotional saliency due to the inherent causality and figurative qualities that they verbalize (Huddleston \& Pullum, 2002: 174; Brannon, 2018: 228). emotions in all of these extracts, providing yet another link to the first three examples in this case study. This possibility allows for a reinforcement of the emotional concepts of growth and pain as both temporary and formative, and as entities which, by way of their influence upon the malleable, flexible, human body/mind, open the possibility for artistic creation and expression: forms of liberty, the ultimate objective and drive of the human spirit, according to the Spinozian view.

\section{4. (Increase in) Body Heat for Love/Emotion}

The next conceptual metonymy to be analyzed is that of (INCREASE IN) BODY HEAT FOR LOVE/ EMOTION $^{10}$. Our corpus has provided us with three occurrences of this metaphor. Once again, they are ordered here in terms of intensity: here, from the least amount of heat expressed to the most.

(17) And for that poor Ambition! It springs / From a man's little heart's short feverfit $[. .$.

“Ode on Indolence," lines 34-35.

(18) For ever panting, and for ever young; / All breathing human passion far above, / That leaves a heart high-sorrowful and cloy'd / A burning forehead, and a parching tongue.

"Ode on a Grecian Urn," lines 27-30.

(19) [...] and to follow them I burn'd / And ached for wings, because I knew the three; [...]

"Ode on Indolence," lines 23-24.

(17) expresses the notion of heat-both cause and effect of the emotional and mental state of ambition-in the terms of "fever": but, as mentioned above, it is a rapid, miniaturized fever. However, it is hot enough to entail-or, the ambition which fueled it was strong enough to kindle-a certain amount of fire. The cause and effect relationship here goes easily in both directions. 
31 (18) presents multiple expressions of the physical effects of the increase in body heat for emotion: "panting," "a burning forehead," and a "parching tongue," all of which are indicative of the passion, which has resulted in the augmentation of the body temperature to desert-like conditions, in which one would have difficulty breathing and could be close to dehydration. The intense nature of the heat described here is thus reflective of the intensity of the emotion experienced, reinforcing both by way of image and reference to physicality the poetic expression of emotion in these lines. Furthermore, we may remark upon the inherent contrast between the intrinsic qualities of the Grecian Urn itself and the highly volatile passion expressed by way of this conceptual metonymy, rendering the metonymy all the more potent.

(19) reflects a similar intensity to that expressed in (18), as the speaker burns with emotion: here, the desire to follow the three graces which remains present throughout the poem. The burning, coupled with the aching described in line 24, which is also indicative of the speaker's desire to follow the three angelic entities, all the more magnifies the heightened emotional content of these verses. Furthermore, aching can easily be linked with burning sensations, thus emphasizing the overall increase in temperature verbalized by way of the conceptual metonymy.

\section{5. (Loving, Joyful) Visual Behavior for Love / Facial Expressions}

The next conceptual metonymy to be analyzed here is (LOVING, JOYFUL) VISUAL BEHAVIOR FOR LOVE / FACIAL EXPRESSIONS (Kövecses, 2000: 124). We have chosen to place "loving, joyful" within parentheses in the title of the conceptual metonymy, due to the fact that the conceptual metonymy upon which mine is based necessarily included one or both of these adjectives. However, to fully analyze the universality of the emotion of love expressed by way of visual behavior, the decision was made to extend the metonymy to any type of visual behavior that could be indicative of love; and these visual comportments are not always joyful or necessarily "loving" in the moment. Our corpus provides five instances of this conceptual metonymy: they are arranged in the order of the least jubilant to the most expressive of joy.

(20) If Isabel's quick eye had not been wed / To every symbol on his forehead high; / she saw it waxing very pale and dead, / And straight all flush'd: [...]

"Isabella, or the Pot of Basil," lines 51-54.

(21) If looks speak love-laws, I will drink her tears, [...]

"Isabella, or the Pot of Basil," line 39.

(22) She looked at me as she did love, / And made sweet moan [...]

“La Belle Dame Sans Merci," lines 19-20.

(23) Where Beauty cannot keep her lustrous eyes, / Or new Love pine at them beyond tomorrow.

"Ode to a Nightingale," lines 29-30.

(24) And if you smile, the blushing while, / Then maidenheads are going. "O blush not so!" lines 3-4. 
(20), (21), and (22) verbalize visual behavior which could be described as an act, or a reflection, of deep attachment, and given the contexts in which they are placed, thus indicative of the emotion and exchange of love. The notion of attachment is expressed in varying ways: in (20), we find Isabella's eye "wed to every symbol" on Lorenzo's forehead. The lexical verb wed not only refers to romantic love by default, but also, to legal attachment, thus emphasizing the depth of the physical and emotional attachment between the two lovers. In (22), once again, from "Isabella," we find the visual behavior expressed in terms of legality-"if looks speak love-laws"-once again providing an elevated quality to the attachment, and thus, love, manifested by way of Isabella's visual behavior towards Lorenzo. (22) creates a parallelism between the act of loving and the visual behavior that La Belle Dame engages in during this specific act. This provides a doubling-up of the intensity of the emotion expressed by these two behaviors, thus, a multiplicity within the expression of love, portraying it as more dynamic and tangible on various levels. Furthermore, it renders the hopelessness of the Knight in the poem all the more powerful once this emotion is no longer present within his frame of emotional operation.

(23) and (24) verbalize more joyful and beatific visual behavior. In (24) we find this coupled with the expression of a smile. However, in (23), we find the subjects (Beauty and Love) who are intended to engage in this lighthearted, ecstatic behavior (keeping one's lustrous eyes, and then, pining after them) unable to act, due to the murky and glum atmosphere which characterizes the poem at this point. This incapacity to fulfill such behavior emphasizes the necessity of an emotional state centered around love for such visual behavior. (24) is presented more in a context of lust-leaning towards love, but perhaps not quite there yet-in which the "smile" is reflective of the emotional state of the woman described in the poem. A genuine smile necessarily implies visual reactions (Ekman, 1992: 36), hence the motivation behind the consideration of this extract as an instance of (LOVING, JOYFUL) VISUAL BEHAVIOR FOR LOVE / FACIAL EXPRESSIONS. We can also take note of the inclusion of "the maidenheads are going" as a secondary reinforcement for the existence of a love/lust relationship in these lines, as another physical expression of the emotion of love.

\subsection{Change in Respiration for Emotion}

The next metonymy to analyze is CHANGE IN RESPIRATION FOR EMOTION (Kövecses, 2000: 134), of which we have two occurrences, from "O blush not so!" and from "Ode on a Grecian Urn." We have arranged them in terms of the intensity of the respiration depicted within the verses:

(25) O sigh not so! O sigh not so! / For it sounds of Eve's sweet pippin; [...] "O blush not so!" lines 9-10.

(26) For ever panting, and for ever young; / All breathing human passion far above, / That leaves a heart high-sorrowful and cloy'd / A burning forehead, and a parching tongue.

"Ode on a Grecian Urn," lines 27-31.

(25) refers to sighing: thus, unnatural breathing that almost always is reflective of a particular emotional state. The metonymy for emotion (here, love, lust, and/or desire) is 
clearly indicated within these two verses. The sigh is directly referred to as reflective of the emotional state of the young lady in the poem, which, conversely, incites emotion in the speaker: hence his exhortation that she avoid this particular physical expression.

(26), previously analyzed in the occurrences of (INCREASE IN) BODY HEAT FOR LOVE/EMOTION, emphasizes the changes in breathing patterns as reflective of the intensity of the heatthe passion-experienced within the "Ode on a Grecian Urn." The "panting," the "breathing human passion," and even the "parching tongue" are reflective of the intensification of breathing patterns, a secondary physical expression of the flames of passion nearly devouring the protagonist in these lines.

\subsection{Sex for Love}

Our next emotional, conceptual metonymy to examine is that of SEX FOR LOVE (Kövecses, 2000: 124), of which we have three occurrences, two of which have been examined in previous metonymical cases.

(27) Yet even in these days so far retir'd / From happy pieties [...] I see, and sing, and by my own eyes inspir'd. / So let me be thy choir, and make a moan / Upon the midnight hours; [...]

"Ode to Psyche," lines 40-45.

(28) She looked at me as she did love, / And made sweet moan [...]

"La Belle Dame Sans Merci," lines 19-20.

(29) O blush not so! O blush not so! / Or I shall think you knowing; / And if you smile, the blushing while, / Then maidenheads are going.

"O blush not so!" lines 1-4.

In (27) and (28), the sexual act-representative of the emotion of love, which is, moreover, clearly explicit in (28) - is depicted in regard to the auditory and verbal senses: that is, the moan. The poet leaves no room for doubt in these references, as the context clarifies the act of sexual intercourse ("as she did love"), as well as its spatial and temporal ("upon the midnight hours") contexts, as well as the tone of the auditory output ("sweet.")

In (29), the sexual act is not necessarily referred to as taking place within the enunciation itself. The references to the loss of virginity, however, ("then maidenheads ${ }^{11}$ are going") in conjunction with the conceptual metonymies BLUSHING FOR LOVE and (LOVING/JOYFUL) VISUAL BEHAVIOR FOR LOVE render the situation quite clear, and furthermore, reinforce the lusty, amorous atmosphere, characteristic of the poem in its entirety.

Despite the fact that the instances of conceptual metonymy are quite clearly enunciated in these extracts, we can note that the lexical, semantic, and conceptual contexts play a very important supporting role in the full elaboration of the metonymy in these cases.

\subsection{Incapacitating Effects of the Emotion for the Emotion}

The third-to-last metonymy to be analyzed here, of which our corpus has presented only one occurrence, is INCAPACITATING EFFECTS OF THE EMOTION FOR THE EMOTION (Kövecses, 2000: 
82). The verses have been previously analyzed, so the analysis to follow may be taken as complementary to the previous analysis.

(30) My heart aches, and a drowsy numbness pains / My sense, as though of hemlock I had drunk, / Or emptied some dull opiate to the drains / One minute past, and Lethe-wards had sunk...

"Ode to a Nightingale," lines 1-4. would encounter after having consumed hemlock or a similar substance: a numbing, jading sensation, ultimately rendering its experiencer incapacitated on multiple levels, but most importantly, in terms of the ability to experience sensation and emotion. Ironically, this overall lackluster, attenuating emotional quality is the direct result of another emotion-the overwhelming atmosphere of hopelessness found at the beginning of the poem-and leads to the lack of further emotion. These verses are rife with lexical elements which act as reinforcement for the metonymy, such as "drowsy numbness," "dull," "drains," and "sunk."

\subsection{Inability to Speak for Emotion}

again, as is always the case with "Isabella," we are in the context of the experience of first love by two young lovers. Here, we have Lorenzo, unable to speak, due to the intensity of the love and emotion he feels for his beautiful Isabella. His voice is not only "stifled," but his resolve is also "pulsed away." Moreover, these lines emphasize the inner turmoil experienced by Lorenzo, a sort of va-et-vient expressed by way of the images of the "ruddy tide," and his ability to speak, or "pray," inwardly, but not externally, leading us back to the interior alcoves of the individual, the birthplace of emotion and feeling.

\subsection{Crying for Sadness}

47 Our final conceptual metonymy is perhaps one of the simplest and most common conceptual metonymies for emotion-CRYING FOR SADNESS ${ }^{12}-$ but is presented in these lines with an inherent complexity, as the actual act of the physical expression does not fully manifest itself. The example is found in "Ode on Indolence":

(35) Tho' in her lids hung the sweet tears of May [...] / O Shadows! 'twas a time to bid farewell! / Upon your skirts had fallen no tears of mine.

“Ode on Indolence," lines 46; 49-50. 
48

act of shedding tears here is referred to as an appropriate response to the act of saying farewell: typically a moment which could incite emotions of sadness, despair, or regret. However, we have here a speaker who, as has already been mentioned, is numb and indolent, and therefore is unable to, or refuses to, engage himself in and manifest this kind of emotion and hence this kind of emotional response. This thus reinforces the notion that the speaker does not actually feel sadness in this given moment ${ }^{13}$. The lack of physical expression may be analyzed here as metonymy for lack of emotion, which strengthens the force of conceptual metonymy in the poem, as well as the role of conceptual metonymy in our perception and apprehension of emotion in general.

\section{Conclusion}

he above pages have provided an overview of the multiple conceptual metonymies relative to bodily expression of emotion within our Keatsian corpus, based on both philosophy and neuroscience with conceptual approaches to linguistic expression, so as to examine and decipher the ways in which the role of the body/mind is present in verbalizations of emotional experience within our Keatsian corpus. By way of these examples and their analyses, we have seen, first and foremost, that the role of the body in the Keatsian comprehension of emotion is of the utmost centrality. Keats's oeuvre is not lacking in highly elaborated, dynamic, representations of the body within emotional experience. Moreover, these analyses have allowed us to account for the foundational presence of what we may refer to as "master metonymies for emotion": PHYSIOLOGICAL AND EXPRESSIVE RESPONSES OF AN EMOTION FOR AN EMOTION and EFFECTS OF A STATE FOR THE STATE. The more precise or specific conceptual metonymies analyzed above have either one or both of these metonymies as their starting-off point. The metonymies that follow are understood as more specific delineations of these metonymies, relative to specific aspects of the emotion itself. In regard to grammar, we can also note an overwhelming use of the perfective, or non-progressive aspect (with the exception of one or two examples)providing a maximal viewing frame (Radden \& Dirven, 2007: 177) while simultaneously injecting dynamicity into the expressions in which it is found-reflective of the highly universal quality of the role of the body in emotional experience.

Furthermore, we have seen that a wide variety of emotions-and more particularly, "aspects of emotion concepts" (Kövecses, 2000: 4)-are represented by way of the emphasis of the body within Keats's works. This is often done by the exploitation of verbalization of conceptual metonymy so as to describe the moment of the "emergence" of the emotion: that is, the moment when the emotion is consciously felt and observed by the experiencer. The verbalizations of conceptual metonymies for this specific moment allow for a full expression of the emotional experience, with the facets of the experience of the emotion itself shaping the language we use to refer to it, while molding our perception of the emotion itself. Conceptual metonymy thus plays an essential role in the ways in which we comprehend and respond to emotion, and this includes both the mind and the body, if we choose to separate the two (which, is a highly questionable act, based on the views of Spinoza which render the link between the body/mind, emotion, and linguistic expression so clear [LeBuffe, 2015]).

51 Finally, we may see the Keatsian verbalizations of conceptual metonymy for the emotions as multi-faceted, multi-layered, complex structures in terms of their lexical choices,

TIPA. Travaux interdisciplinaires sur la parole et le langage, 35 | 2019 
semantics, and grammatical usage. All of these elements work together within the verbalization of metonymy to create functioning and poetic metonymies. We can even visualize Keatsian verbalizations of these conceptual mappings as reflective of the interactions within our bodies and minds when we experience emotion: each element is essential and plays its own specific role, both alone and in conjunction with its surrounding elements and its context, resulting in the fascinating, beautiful, and disorderly expressions of emotion itself.

\section{BIBLIOGRAPHY}

Bachelard, Gaston (1943) Le droit de rêver. Paris: Presses Universitaires de France.

Brannon, Katrina A Cognitive Approach to Emotional Language in the Poetry of John Keats. Doctoral dissertation in linguistics. Sorbonne Université, November 2018. Supervised by W. Rotgé.

Damasio, Antonio (1999) The Feeling of What Happens: Body and Emotion in the Making of Consciousness. New York: Harcourt Inc.

Damasio, Antonio (2003) Looking for Spinoza: Joy, Sorrow, and the Feeling Brain. Mariner Books.

Dirven, René \& Günter Radden (2007) Cognitive English Grammar. Amsterdam: John Benjamins.

Ekman, Paul (1992) Facial Expressions of Emotion: New Findings, New Questions, Psychological Science, vol. 3, 1, p. 34-38.

Huddleston, Rodney \& Geoffrey K. Pullum (2002) A Cambridge Grammar of the English Language. Cambridge: Cambridge University Press.

Keats, John (2001) Complete Poems and Selected Letters of John Keats, New York: The Modern Library.

Langacker, Ronald W. (2008) Cognitive Grammar: A Basic Introduction. Oxford [etc.]: Oxford University Press.

Langacker, Ronald W. (2000) Grammar and Conceptualization. Berlin, New York: Mouton de Gruyter, 2000.

Tsur, Reuven (2008) Towards a Theory of Cognitive Poetics, Second Expanded Edition. Sussex: Academic Press.

Kövecses, Zoltán (1990) Emotion Concepts. New York: Springer Verlag.

Kövecses, Zoltán (2000) Metaphor and Emotion: Language, Culture, and Body in Human Feeling. Cambridge, New York: Cambridge University Press.

Kövecses, Zoltán (2008) Metaphor and Emotion.in R. W. Gibbs (ed) The Cambridge Handbook of Metaphor and Thought. New York [etc.]: Cambridge University Press.

Lakoff, George \& Mark Johnson (1980) Metaphors We Live By. Chicago, London: University of Chicago Press.

Lakoff, George \& Mark Turner (1989) More than Cool Reason: A Field Guide to Poetic Metaphor. Chicago, London: University of Chicago Press. 
LeBuffe, Michael (2015) Spinoza's Psychological Theory, in Edward N. Zalta (ed.) The Stanford Encyclopedia of Philosophy. Disponible sur :

https://plato.stanford.edu/archives/spr2015/entries/spinoza-psychological/.

Radden, Günter \& Zoltán Kövecses (2009) Towards a Theory of Metonymy, in. Klaus-Uwe Panther \& Günter Radden (Eds) Metonymy in Language and Thought, Philadelphia, Amsterdam: John Benjamins, p. 17-59.

Sartre, Jean-Paul (1939) Esquisse d'une théorie des émotions, Paris: Hermann

\section{NOTES}

1. La traduction est de nous.

2. La traduction est de nous.

\section{ENDNOTES}

1. "The poet puts a more subtle dialectic into action. He reveals, simultaneously, at the same instant, the solidarity of the shape and of the person. He proves that the shape is a person and that the person is a shape." (Translation mine).

2. The "idealized cognitive model," a notion proposed by G. Lakoff (1987), "is meant to include not only people's encyclopedic knowledge of a particular domain but also the cultural models they are a part of," (Radden \& Kövecses, 2009: 20).

3. Whether or not the role of consciousness played an essential role in the experiencing of emotion for Spinoza himself (and thus, within his philosophy) is rather unclear, although A. Damasio's definition of consciousness is highly relatable to the Spinozian conatus in the sense that "at its simplest and most basic level, consciousness lets us recognize an irresistible urge to stay alive and develop a concern for the self," (Damasio, 1999: 5); or, in other words, "Spinoza said that the effort to preserve oneself is the first and unique foundation of virtue. Consciousness enables that effort," (Damasio, 1999: 25).

4. "To be sure, at this point in evolution and at this moment in our adult lives, emotions occur in a setting of consciousness. We can feel our emotions and we know we feel them," (Damasio, 1999: 43).

5. "État de conscience." (Translation mine).

6. "La conscience émue." (Translation mine).

7. A. Damasio also provides a definition for what he calls "extended consciousness," which he specifically relates to creativity: "If it is true that core consciousness is the rite of passage into knowing, it is equally true that the levels of knowing which permit human creativity are those which only extended consciousness allows. When we think of the glory that is consciousness, and when we consider consciousness as distinctively human, we are thinking of extended consciousness at its zenith," (Damasio, 1999: 17).

8. See Lakoff \& Johnson, 1980.

9. The conceptual metonymies upon which our analyses are based have been directly taken from, or inspired by Kövecses 2000, (listed in the Metaphor and Metonymy Index ([p. 222-223]). 
10. Based on Z. Kövecses's BODY HEAT FOR EMOTION (Kövecses, 2000: 134).

11. Maidenhead (archaic): "the state or condition of a maiden; virginity [...]" (OED, 1989: vol. IX, 210). We may also note that maidenhead is typically employed as a non-count noun, so its plural usage is rather surprising.

12. Based on Z. Kovecses's CRYING FOR ANGER (Kövecses, 2000: 171).

13. This is explicitly manifested at the end of the poem: "So, ye three Ghosts, adieu! Ye cannot raise / My head cool-bedded in the flowery grass; / For I would not be dieted with praise, / A petlamb in a sentimental farce! / Fade softly from my eyes, and be once more / In masque-like figures on the dreamy urn; / Farewell! I yet have visions for the night, / And for the day faint visions there is store; / Vanish, ye Phantoms! from my idle spright, / Into the clouds, and never more return!" (v. 51-60).

\section{ABSTRACTS}

This article focuses on the linguistic expression of emotion and emotional experience by way of conceptual metonymy, and will thus be centered on the physical and/or physiological, and perhaps, more tangible, aspects of emotion. The aim of this study is, primarily, to analyze the occurrences of conceptual metonymy related to emotion found in the Keatsian corpus upon which this research is founded. This type of analysis necessarily highlights the central role that the body holds in emotional experience and our linguistic expressions of said experience, and furthermore, how the verbalization of emotional experience necessitates consciousness of the emotional experience on the part of the agent. This allows for an examination of emotion in its multiple dimensions, all the while solidifying the parallelism between the body and the mind, or, the inherent embodiment of emotion.

Cet article nous livre une analyse de l'embodiment (cognition incarnée) de l'expérience émotionnelle et de ses verbalisations dans le corpus keatsien, et plus particulièrement, l'expression de l'expérience émotionnelle à travers la métonymie conceptuelle. Cette concentration sur la métonymie conceptuelle nous permettra de nous focaliser sur les aspects physiques / physiologiques - peut-être les plus concrets - de l'émotion. Les théories acceptées de la métonymie conceptuelle et l'émotion incarnée, ainsi que les recherches effectuées sur le corpus keatsien qui sert de fondation à cette recherche - une trentaine de poèmes de John Keats, écrits tout au long de sa carrière et de style et taille diverses - nous ont mené au constat que l'analyse de la métonymie conceptuelle en tant que moyen de l'expression de l'émotion serait la manière la plus riche et évocatrice d'analyser le domaine physiologique de l'émotion. Les analyses effectuées dans cet article sont le résultat d'une combinaison des (embodied) théories de l'émotion qui ont pour fondement la philosophie et la neuroscience et des approches conceptuelles de l'expression linguistique, dans le but d'examiner et de décrypter les différentes manières dont le corps/esprit est présent dans les verbalisations de l'expérience émotionnelle au sein de notre corpus.

Le but de ce texte est d'examiner la façon dont le corps/esprit se révèle(nt) présent(s) au sein de la conceptualisation et réalisation de l'émotion dans l'œuvre keatsienne. G. Bachelard nous rappelle l'importance de cette sorte d'expression au sein du texte poétique : « le poète anime une dialectique plus subtile. Il révèle à la fois, dans le même instant, la solidarité de la forme et de la personne. Il prouve que la forme est une personne et que la personne est une forme » (Bachelard 1943: 232).

Le texte s'ouvre par un développement théorique du concept de l'embodiment et de ses rôles et conséquences au sein de l'expression linguistique de l'émotion, ainsi qu'une analyse et définition de la métonymie conceptuelle. Dans les métonymies examinées au cours de cet article, les 
expressions physiologiques / physiques de l'émotion (i.e. des larmes, le rougissement, des changements de température corporelle, les variations de rythme cardiaque...) seront considérées comme le véhicule qui ouvre les portes à la fois linguistiques et cognitives à l'expérience émotionnelle en soi, qui adopterait alors le rôle du domaine cible. Nous définissons le domaine " physiologique » de l'émotion par les effusions physiques (internes et externes) de l'expérience émotionnelle. Pour nous, l'expérience émotionnelle, comprend ses verbalisations linguistiques - la manière dont nous exprimons l'émotions par le biais du langage - étant donné que «les métonymies conceptuelles émotionnelles reflètent, de manière générale, une physiologie universelle et réelle» (Kövecses $2000: 177)^{1}$.

Nous constatons que l'omniprésence du corps dans l'œuvre keatsienne offre une grande variété d'émotions-et plus spécifiquement, des « aspects des concepts émotionnels " (Kövecses $2000: 4)^{2}$ . Cela est fréquemment dû à l'emploi de la métaphore et la métonymie conceptuelles, à l'origine de la description, par le poète, au moment de «l'émergence » de l'émotion : à savoir, le moment où l'émotion est ressentie de manière consciente et observée par celui qui l'expérimente. Les verbalisations de la métonymie conceptuelle, à ce moment particulier, livrent une puissante charge d'expression émotionnelle : les facettes de l'expérience émotionnelle elle-même façonne le langage qui permet d'exprimer celle-ci, ainsi que notre perception intérieure de l'émotion. La métonymie conceptuelle joue donc un rôle clé dans la manière dont nous comprenons et répondons à l'émotion, incluant le corps et l'esprit, dès lors que nous les distinguons.

Les métonymies conceptuelles analysées au sein de ce texte sont les suivantes : CHANGE IN COLOR OF FACE FOR EMOTION (BLUSHING FOR LOVE) ; CHANGE IN HEART RATE FOR EMOTION ; PHYSICAL AGITATION FOR EMOTION ; (INCREASE IN) BODY HEAT FOR LOVE/EMOTION ; (LOVING, JOYFUL) VISUAL BEHAVIOR FOR LOVE / FACIAL EXPRESSIONS ; CHANGE IN RESPIRATION FOR EMOTION ; SEX FOR LOVE ; INCAPACITATING EFFECTS OF THE EMOTION FOR THE EMOTION ; INABILITY TO SPEAK FOR EMOTION ; CRYING FOR SADNESS.

Chaque métonymie est examinée à partir d'un ensemble de un à six vers extraits des poèmes suivants: "Ode to a Nightingale ", «Ode to Psyche», "Ode on a Grecian Urn », "Ode on Melancholy », « To Hope », « Ode on Indolence », « Isabella, or the Pot of Basil », « O blush not so! », et « La Belle Dame Sans Merci ».

Les analyses présentées au sein de ce texte soulignent le fait que l'émotion est un assemblage complexe de perceptions, moments et interactions, qui sont tous fondés sur notre système conceptuel et notre fonctionnement physique. Enfin, nous pouvons concevoir les verbalisations keatsiennes de la métonymie conceptuelle propre à l'émotion comme des structures complexes et multiformes au regard de leurs choix lexicaux et sémantique comme de leur usage grammatical. Grâce aux exemples tirés de notre corpus ainsi que leurs analyses, nous pouvons voir, que le corps joue un rôle central dans l'œuvre de Keats. De plus, nos analyses nous permettent de rendre compte ce que nous appelons les « métonymies maîtresses de l'émotion » : à savoir, PHYSIOLOGICAL AND EXPRESSIVE RESPONSES OF AN EMOTION FOR AN EMOTION et EFFECTS OF A STATE FOR THE STATE. Les métonymies qui suivent (mentionnées ci-dessus) sont donc comprises comme des délinéations plus spécifiques, relatives aux aspects particuliers de chaque émotion. Quant à la grammaire, nous notons le recours fréquent à l'aspect perfectif, ce qui reflète directement la qualité universelle du rôle du corps dans l'expérience émotionnelle. Ces verbalisations dynamiques ont principalement lieu lors du moment de «l'émergence » émotionnelle : c'est-àdire, le moment où l'émotion est ressentie et observée sciemment par celui qui la vit.

Tous ces éléments travaillent ensemble, avec la verbalisation de la métonymie, afin de créer des métonymies qui fonctionnent et qui sont poétiques. Il est même possible de visualiser les verbalisations keatsiennes de ces cartographies conceptuelles, en tant que reflets des sensations et interactions vécues dans notre corps et notre esprit lorsque nous éprouvons une émotion : chaque élément se révèle essentiel et joue son propre et unique rôle, à la fois seul et conjointement avec les éléments qui l'entourent dans son contexte, en véhiculant les expressions fascinantes et chaotiques de l'émotion elle-même. 
INDEX

Keywords: conceptual metonymy, Keats, emotion, embodiment, cognitive poetics, cognitive linguistics

Mots-clés: métonymie conceptuelle, Keats, émotion, cognition incarnée, poétique cognitive, linguistique cognitive

\section{AUTHOR}

\section{KATRINA BRANNON}

Sorbonne Université (EA 7332 CeLiSo)

Université Paris 8 - Vincennes - Saint-Denis

katrina.ann.brannon@gmail.com 